Jurnal ASPIKOM, Vol. 6, No. 2, July 2021, pp. 222-234

P-ISSN: 2087-0442, E-ISSN: 2548-8309

DOI: http://dx.doi.org/10.24329/aspikom.v6i2.907

\title{
Mapping Disinformation During the Covid-19 in Indonesia: Qualitative Content Analysis
}

\section{Pemetaan Disinformasi Selama Pandemi Covid-19 di Indonesia: Analisis Isi Kualitatif}

\author{
Devie Rahmawati $^{1 *}$, Deddy Mulyana ${ }^{2}$, Giri Lumakto ${ }^{3}$, Mila Viendyasari ${ }^{4}$, \\ Wiratri Anindhita ${ }^{5}$ \\ 1,3,4 Universitas Indonesia, Jl. Margonda Raya, Pondok Cina, Depok, Indonesia \\ ${ }^{2}$ Universitas Padjajaran, Jl. Raya Bandung Sumedang KM 21, Bandung, Indonesia \\ ${ }^{5}$ Universitas Negeri Jakarta, Jl. Ramawangun Muka Raya No.11, Jakarta, Indonesia \\ *Corresponding author, e-mail: devie.r@ui.ac.id
}

\begin{abstract}
During life-threatening situations such as the Covid-19 pandemic, disinformation is rife. While people project their affective aspects into understanding the situation, their fear of Covid19 interferes with their logical and reasonable assessment of disinformation. Less credible information such as rumors becomes reliable for some people. This study aims to map the disinformation category based on the Ministry of Communication and Information report from January to March 2020. There are 359 hoaxes with five categories and 30 sub-categories. This study uses qualitative content analysis as a method. The study results revealed that most of the disinformation during the Covid-19 pandemic was related to the spread of hoaxes on health issues. This research implies that several recommendations are made to respond to the urgency of handling disinformation during Covid-19 in Indonesia, such as initiating digital literacy and media literacy in the national education system.
\end{abstract}

Keywords: Content analysis; Covid-19; Disinformation; Qualitative

\begin{abstract}
Abstrak
Selama situasi yang mengancam jiwa seperti pandemi Covid-19, disinformasi menyebar luas. Sementara orang memproyeksikan aspek afektif mereka dalam memahami situasi, ketakutan mereka terhadap Covid-19 mengganggu penilaian logis dan masuk akal mereka terhadap disinformasi. Informasi yang kurang kredibel seperti rumor menjadi dapat diandalkan untuk beberapa orang. Penelitian ini bertujuan untuk memetakan kategori disinformasi berdasarkan laporan Kementerian Komunikasi dan Informasi dari Januari hingga Maret 2020. Terdapat 359 hoax dengan 5 kategori dan 30 sub kategori. Penelitian ini menggunakan analisis isi kualitatif sebagai metode. Hasil penelitian mengungkapkan bahwa sebagian besar disinformasi selama pandemi Covid-19 terkait penyebaran hoax isu kesehatan. Implikasi dari penelitian ini mengemukakan beberapa rekomendasi menanggapi urgensi penanganan disinformasi selama Covid-19 di Indonesia, seperti menginisiasi literasi digital dan literasi media dalam sistem pendidikan nasional
\end{abstract}

Kata Kunci: Analisis konten; Covid-19; Disinformasi; Kualitatif 


\section{Introduction}

Disinformation and propaganda on social media have attracted the public (Seo, 2014). As we know, disinformation had existed since 1946, where Allport and Postman (1946) in Pulford (2019) explained that rumor travels when events are important in individuals' lives and when the news received about them is either subjective or ambiguous. It reminds and reflects our current Covid-19 pandemic. According to Ali (2020), everyone was scared and worried about their own lives. In the meantime, Covid19 news was ambiguous and made sense of rumor. Scherr et al. (2021) assert that vague news impacts negative information. In our contemporary digital world, we called this misleading news disinformation (Arthur, 2017). We can discern that the confusion of news consumption that happened in World War I is repeated today. It is indeed relevant to our present Covid-19 pandemic (Viswanath, Lee, \& Pinnamaneni, 2020).

Rumors en masse are challenging to handle. Therefore, social media platforms like Twitter consider themselves aggregators of information such as disinformation in the Taliban war propaganda (Bahar, 2020). Unfortunately, the prevalence of social media platforms has amplified the circulation and outreach of disinformation. Two core elements of social media, namely web 2.0 and User-Generated Content (UGC), complicate the information environment. The flow of UGC on the web foundation has so long supported the spread of information (Zajc, 2015). However, this mechanism approves disinformation circulation on the public timeline. Disinformation has affected many aspects of our life such as politic (Freelon \& Wells, 2020), law (Craufurd Smith, 2019), health (Chou, Gaysynsky, \& Cappella, 2020), social life (Rampersad \& Althiyabi, 2020), and on technology(McDougall, Brites, Couto, \& Lucas, 2019).

While most users swamped themselves in the types mentioned above of disinformation, they were left in awe by pandemic rumors. In times of panic, when life matters most, words can become believable (Jamil \& Appiah-Adjei, 2020). Research by Guo and Zhang (2020) explained that rumors travel during the time, and individuals' lives are at stake. Guo (2020) explains that rumors may become conceivable when the news about them and the ongoing events are ambiguous. Therefore, half-baked news reporting gave prominence to ambiguity (Koivisto, 2015). Thus, people seem incapable of comprehending the news.

Sunstein (2014) classifies the spreading mechanism, namely, social cascades and group polarization. Cascades mechanism ensues as people rely heavily on each other's thoughts and conduct. For example, when one feels lacking information, the person might approve the views of others. A social cascade could develop when a group of early movers or influencers, or bellwethers, express verbally or physically to signal others to follow. The second mechanism, group polarization, relates to the homophily nature of groups. It is when like-minded people assemble. Once the group members conduct an in-depth discussion of rumors, they would believe it. Not to complicate the definition, either disinformation or rumors pose similar characters. Cummings and Kong (2019) verified that rumors and disinformation displayed and delivered malicious intentions to persuade people to misleading information.

Academics, governments, and private sectors had disinformation in the SARS outbreak in 2003 (Aaltola, 2012). They have failed to warn us of the disinformation circulation danger. One main factor is the presence of social media platforms and private group chats. They have been overrun by pandemic disinformation daily. At the same time, the public was left to understand and identify rumors by themselves. Financial and social constraints already burden the masses themselves. The chaotic and 
toxic social media landscape could lead people to give up thinking about and looking for facts (Mansur, Saragih, Ritonga, \& Damayanti, 2021). Society can be easily misled by make-believe information during the Covid-19 pandemic. Some actual events supported this proposition. For instance, three $5 \mathrm{G}$ masts were set ablaze in some parts of the UK. The UK society believed that $5 \mathrm{G}$ frequency has been causing coronavirus (Warren, 2020). Likewise, In India, many people started to consume cow dung and urine. They believe these animal leftovers were an alternative cure to coronavirus, even cancer (Nath, 2020). Simultaneously, Indonesian society got the disinformation through WhatsApp groups saying onion could cure Coronavirus or dates fruit may contain coronavirus from bats (Patrick, 2020).

Therefore, Indonesian face quite ample numbers of disinformation during the Covid-19 pandemic. The Ministry of Communication and Informatics, through their website in 2020, detected and fact-checked more than almost 400 coronavirus-related hoaxes (Kominfo, 2020). The total of hoaxes news about Covid-19 numbers was collected from early January to the end of March 2020. It suggests that there were 6 to 7 hoaxes on average circulating daily during these three months. Alongside the distribution of these hoaxes, the public encounters confusion. With more than 150 million Internet users, they used 8 hours on the internet daily through their smartphones. Most Indonesian news or information sources come from YouTube, WhatsApp, and Facebook (We Are Social, 2019). Most Indonesian attitudes and traits create particular concern because of the platforms mentioned earlier unreliable news or information sources. Therefore, disinformation may spread even faster during the pandemic through social media. In line with the research of Mansur et al. (2021), the spread of fake news through social media goes rising because people do not understand the content of the news.

Disinformation may circulate when false information is consciously shared by someone to cause disadvantages to others (Krafft \& Donovan, 2020). The sharer knows precisely the information is incorrect but intentionally shares it regardless. At the same time, mal-information occurs when factual information is shared to cause damage, such as when someone has intentionally distributed the half-true information to the public to spark curiosity. On the other side, the interest usually focused on the private life behind the phenomena (Wardle \& Derakhshan, 2017). Therefore, Bradshaw and Howard (2018) reported disinformation as part of computational propaganda in The Global Disinformation Order from the Oxford Internet Institute. The countries covered in this report were 70 countries in 2019. In March 2019, on Presidential Election, there were 453 hoaxes on average, and there were 15 hoaxes found daily (Kominfo, 2019). Since then, disinformation has become part of our social media life in Indonesia. During this Covid-19 pandemic, hoaxes in the form of rumors have widely spread on social media.

Based on previous research, the researchers aim to map the distribution of disinformation related to the Covid-19 pandemic. The researchers are trying to find variations of disinformation from January to March 2020, according to the Kominfo clarification report. Furthermore, the researchers analyzed hoax content using content analysis techniques. The content analysis is carried out through rumors theory. The purpose of this study is to analyze the mapping of disinformation related to the Covid19 pandemic. 


\section{Method}

This research is a literature review with the subject of a report from the Directorate General of Informatics Applications, Ministry of Communication and Informatics of the Republic of Indonesia with the title Hoax Issue Report in 2020. To map disinformation during Covid-19, the researcher used qualitative content analysis (Schellekens, Dillen, Dewitte, \& Dezutter, 2020). The analysis was carried out to examine current trends and patterns -the Covid-19 pandemic- as an empirical basis for monitoring shifts in public opinion. This analytical technique is useful and meaningful because it relies on coding and categorizing the data related to disinformation in Covid19 events based on the Republic of Indonesia's Ministry of Communication and Information in 2020 about the Covid-19 hoax report. This study uses a qualitative descriptive method with a content analysis technique approach as the data required descriptive explanation. The following are the categories and sub-categories of data analysis:

Table 1. Categories and Sub-categories of the Data (source: Kominfo, 2020)

\begin{tabular}{|c|c|c|c|c|}
\hline No. & Categories & Sub-categories & Code & Meaning \\
\hline \multirow[t]{5}{*}{1.} & \multirow{5}{*}{$\begin{array}{l}\text { What: The subject of the } \\
\text { hoax's utterances or } \\
\text { sentences }\end{array}$} & People & PEP & A subject is a person. \\
\hline & & Action & ACT & $\begin{array}{l}\text { The subject is an activity } \\
\text { or action. }\end{array}$ \\
\hline & & Phenomenon & PHE & A subject is an event. \\
\hline & & Place & PLA & $\begin{array}{l}\text { The subject is a location or } \\
\text { venue. }\end{array}$ \\
\hline & & Medicine & MED & $\begin{array}{l}\text { The subject is drugs or } \\
\text { medical entities. }\end{array}$ \\
\hline \multirow[t]{8}{*}{2.} & \multirow{8}{*}{$\begin{array}{l}\text { Who: The object or the } \\
\text { things discussed in the } \\
\text { hoax's utterances or } \\
\text { sentences }\end{array}$} & Figure & FIG & $\begin{array}{l}\text { The object is common } \\
\text { people or laymen. }\end{array}$ \\
\hline & & $\begin{array}{l}\text { Very } \\
\text { Important } \\
\text { Person }\end{array}$ & VIP & $\begin{array}{l}\text { The object is a well-known } \\
\text { figure. }\end{array}$ \\
\hline & & Others & OTH & $\begin{array}{l}\text { The object is discussed } \\
\text { other than the things in the } \\
\text { sub-categories. }\end{array}$ \\
\hline & & $\begin{array}{l}\text { Alternative } \\
\text { Medicine }\end{array}$ & ALT & $\begin{array}{l}\text { The object is an alternative } \\
\text { cure or practice. }\end{array}$ \\
\hline & & Public Places & PUB & $\begin{array}{l}\text { The object is/are public } \\
\text { places. }\end{array}$ \\
\hline & & $\begin{array}{l}\text { Commercial } \\
\text { Places }\end{array}$ & COM & $\begin{array}{l}\text { The object discussed is/are } \\
\text { commercial venues. }\end{array}$ \\
\hline & & $\begin{array}{l}\text { Health } \\
\text { Facilities }\end{array}$ & HFA & $\begin{array}{l}\text { The objects discussed } \\
\text { is/are health facilities. }\end{array}$ \\
\hline & & Technology & TEC & $\begin{array}{l}\text { The objects are } \\
\text { technological tools, } \\
\text { devices, and systems. }\end{array}$ \\
\hline 3. & $\begin{array}{l}\text { Context: The setting, } \\
\text { meaning, and message } \\
\text { of the hoax's utterances }\end{array}$ & Health & HEA & $\begin{array}{l}\text { The message of the hoax } \\
\text { conveys health issues } \\
\text { caused by Covid-19 }\end{array}$ \\
\hline
\end{tabular}


or sentences.

Security

Measure

Politics

Racism

4. Scope: The targeted place mentioned or implied in the hoax

5 Media: The social media Facebook platform utilized

6 Rumors: Types of rumors implied in the hoax
WhatsApp

Twitter

Internet

Instagram

YouTube

\section{Local \\ International \\ National \\ Regional}

Internet

Dread

Wish

Wedge
SEC The meaning of the hoax conveys the action of preventing and resolving the Covid-19 spread.

POL The meaning refers to political and legal issues to Covid-19 prevention action.

RAS The setting and message of the hoax indicate racial prejudice.

LOC The place mentioned or implied refers to local neighborhood or district

INT The place mentioned or implied refers to abroad countries and locations

NAT The place mentioned or implied refers only to Indonesia.

REG The place mentioned or implied refers to the province.

FAB The hoax distribution social media platform is Facebook.

WHA The hoax distribution social media platform is WhatsApp.

TWI The hoax distribution social media platform is Twitter.

NET The hoax distribution platform is the Internet.

IGM The hoax distribution social media platform is Instagram.

YOT The hoax distribution social media platform is YouTube.

DRE The rumors implied in the hoax incites fear and uncertainty.

WSH The rumors implied in the hoax incite optimism.

WDG The rumors implied in the hoax provoke conflict. 
Table 1 shows the content analysis procedure carried out through six categories: what, who, context, scope, media, and rumors. Therefore, we determined the unit of analysis based on six categories starting from the smallest unit to the largest unit. Data collection was carried out through reading according to the sub-category in Table 1 . The data that has been obtained were then classified based on the code of each category. Data collection was carried out through the process of reading and recording the data related to disinformation in Covid-19. Qualitative content analysis has developed rigorous coding and analysis techniques to obtain validity and reliability (Lebed, 2019). Therefore, this study focuses on creating a bigger picture of the Covid-19 phenomenon embedded in the context (see Table 1). Thus, the procedure carried out is based on Fraenkel and Wallen (2007); namely, the study aims to map the categories of disinformation Covid-19. Then define the terms what, who, context, scope, media, and rumors into sub-categories. The data we get is through the official website of the Ministry of Communication and Informatics of the Republic of Indonesia. Then the selected data is folded into a corpus to facilitate analysis using codes.

\section{Results and Discussion}

The research reveals that during the Covid-19 pandemic, hoaxes were mentioned mostly by common people $(165,46 \%)$. While in the following position, there are actionrelated hoaxes $(62,17,3 \%)$. The gap between PEP and ACT could become an indication that Covid-19 rumors were directed to human-to-human infection. The rumors elaborated mostly on suspected people contracting Covid-19 and the death toll from Covid-19. Simultaneously, action-related rumors like social distancing, regional lockdown, and rapid testing seemed to be the second priority. This phenomenon may relate to the continuum of emergency during a pandemic disaster. In line with Stanley et al. (2020), Covid-19-related hoaxes distribution mentioning people were clearly on the alert phase. The alert phase refers to how people and officials respond to the increase in pandemic cases. Thus, during this phase, the Covid-19 hoaxes prevailed and were widely distributed. Human to human infection is a reality during this phase. Society was afraid, but some hoax purveyors spread dread by circulating false human-to-human infection claims through social media(Susilo, Yustitia, \& Afifi, 2020). In addition to the society fear their life from the Covid-19 virus, peculiar phenomena (PHE) were also visible $(57,15,9 \%)$. In this analysis, abnormal, mythical, or even illogical phenomena happened. For instances, a talking infant claiming egg could cure Covid-19 (348); allegedly mass burial of Covid-19 victims (347); 5G bandwidth was the cause of Covid19 spread (260); Coronavirus was found on toilet tissue (206); some Chinese citizen converted to Islam as they were cured of Covid-19 (127).

Referring to what Ali (2020) defined as rationalizing rumors, these irrational messages circulating during the pandemic are no strange phenomena. During the pandemic, people's minds were positively charged and burdened with fear and worry. Therefore, irrational rumors were not there to be analyzed. Instead, these false claims become rationalization, even fascination for some people. Although indirectly related, hoaxes mentioning medicine (MED) had undergone rationalization $(34,9.5 \%)$. Some of the medicine hoaxes were rationalized as alternative cures (see Table 2).

To compare with, Table 3 shows the number of Covid-19 hoaxes related to the subject of sentences, speeches, and even pictures, which are high $(157,52 \%)$. More than half of the Covid-19 hoaxes were aimed at the general public than figures $(58,16.2 \%)$. They know their lives are also at stake during the pandemic. Society may share the 
belief in saving themselves during the alert phase rather than caring and focusing on figures, such as the President, artists, and religious figures.

Table 2. Numbers of Disinformation Based on What Category

\begin{tabular}{clcc}
\hline No. & \multicolumn{1}{c}{ Code } & $\Sigma \mathrm{n}$ & $\%$ \\
\hline 1. & People (PEP) & 165 & 46 \\
2. & Action (ACT & 62 & 17.3 \\
3. & Phenomena (PHE) & 57 & 15.9 \\
4. & Place (PLA) & 41 & 11.4 \\
5. & Medicine (MED) & 34 & 9.5 \\
\hline
\end{tabular}

Table 3. Numbers of Disinformation Based on Who Category

\begin{tabular}{clcc}
\hline No. & \multicolumn{1}{c}{ Code } & nn & $\%$ \\
\hline 1. & Figures (FIG) & 157 & 52.2 \\
2. & Very Important Person (VIP) & 58 & 16.2 \\
3. & Others (OTH) & 38 & 12.6 \\
4. & Alternative Medicine (ALT) & 32 & 10.6 \\
5. & Public Place (PLA) & 30 & 10 \\
6. & Commercial Place (COM) & 26 & 8.6 \\
7. & Health Facilities (HFA) & 14 & 3.9 \\
8. & Technology (TEC) & 4 & 1.1 \\
\hline
\end{tabular}

Based on the content analysis results in table 4, most of the hoaxes contexts associated with Covid-19 were about health. This phenomenon was as expected. During a pandemic, people would seek health advice, information, and healthcare. The healthrelated context from the hoaxes were more than $60 \%$ (234). Though placed second, the context related to security measures $(80,22,3 \%)$ also indirectly related to health.

Table 4. Numbers of Disinformation Based on Context Category

\begin{tabular}{clcc}
\hline No. & Code & $\Sigma \mathrm{n}$ & $\%$ \\
\hline 1. & Health (HEA) & 234 & 65.2 \\
2. & Security Measure (SEC) & 80 & 22.3 \\
3. & Politics (POL) & 23 & 6.4 \\
4. & Racism (RAS) & 22 & 6.1 \\
\hline
\end{tabular}

Referring to table 4, the hoaxes from HEA and SEC are as follows:

1. Health-related

a. There was a suspect symptomatic individual in Kraton Batang Regional hospital (223)

b. Tom Hanks was confirmed dead after contracting the Covid-19 virus (216)

c. Daniel Radcliff had contracted coronavirus (192)

d. Coronavirus had been spreading in Jakarta because of pork consumption (175)

e. Wet tissue can replace your mask (155)

2. Security measures
a. The closure of Gianyar road in Bali (350)
b. Sukabumi region required a letter of health notice to enter (344)
c. The Pondok Indah Mall closure because one Covid suspect had entered it (333)
d. A market in Cianjur had to be closed because of Covid-19 (322)
e. Closure and disinfecting in a market in Madiun East Java (286) 
Both health-related and security measure hoaxes eventually related to each other when someone has allegedly contracted Covid-19 while entering commercial venues. These places would soon be reported as having a closure or disinfection prevention by spraying disinfectant solution. While politically-laden and racist rumors also had something frequently apparent. The POL and RAS hoaxes' findings related to; 1) government policy and action; 2) and Chinese ethnicity accusation. Some examples are as follows: Prabowo has gone during the Coronavirus pandemic (309), the Indonesian Ministry of Foreign Affairs announced a lock-down action (277), The medicine that the President has purchased from China are dangerous (334), and Chinese tourists have been freely entered and doing transit flight in Indonesia (173).

Further, the majority of local scope hoaxes usually suggested closedown or disinfection spraying activities. The regional context rumors were 157 hoaxes or $43.7 \%$ among the 395 hoaxes. These local regions represented almost the entire Indonesian archipelago. For international scope rumors ranging from countries like China, India, Italy, Singapore, and Australia $(121,33.7 \%)$. These countries usually have high reports on Covid-19 victims. Most of these international rumors have been contextualized linguistically to Bahasa Indonesia. In other words, they have been translated. Finally, in the third position, national-context hoaxes have also been circulating during the early stage of the Covid-19 pandemic in Indonesia (52, 14.5\%).

Based on content analysis, there were two leading platforms rumors about Covid19 spread. The first was through Facebook $(142,39.6 \%)$ and slightly lower was through WhatsApp $(122,34 \%)$. Both platforms hold almost $70 \%$ of the rumor distribution. Other platforms that had been detected to spread these rumors were Twitter $(48,13.4 \%)$, Internet or online news portal (27, 7.5\%), Instagram (10, 2.8\%), and YouTube $(10,2.8)$. Regarding the numbers of disinformation based on rumors, more than half were about dread (67.1\%) as the report of hoaxes tracking from Hoax Issue Report in 2020 used in this research was at the on set of the Covid-19 pandemic in Indonesia. Rumors conveying fear of Covid-19 contraction and even death were common from January to the end of March 2020. These were the months in which Covid-19 had been globally spread. And during these months also, many countries had been conducting many security measures to prevent Covid-19 infection. From the need to regulate social distancing, washing hands, using sanitary hand spray to regional lock-down was apparent. These activities would have indicted the fear of Covid-19 infarction.

Along with dread rumors, wishful $(70,19 \%)$ and wedge $(48,13.3 \%)$ rumors circulated in social media. Wishful rumors during the Covid-19 pandemic contained hope and dreams of remedial treatment and alternative medicine. While wedge rumors provoked or incite hate toward political preferences, religious belief, ethnicity, or character assassination. So those people who received this wedge rumor could feel angry or hate toward the person or things implied. Though both rumorss numbers were indistinct to dread rumors, either rumors were circulating to the shroud, even more, the toxic information ecosystem during Covid-19 pandemic. 


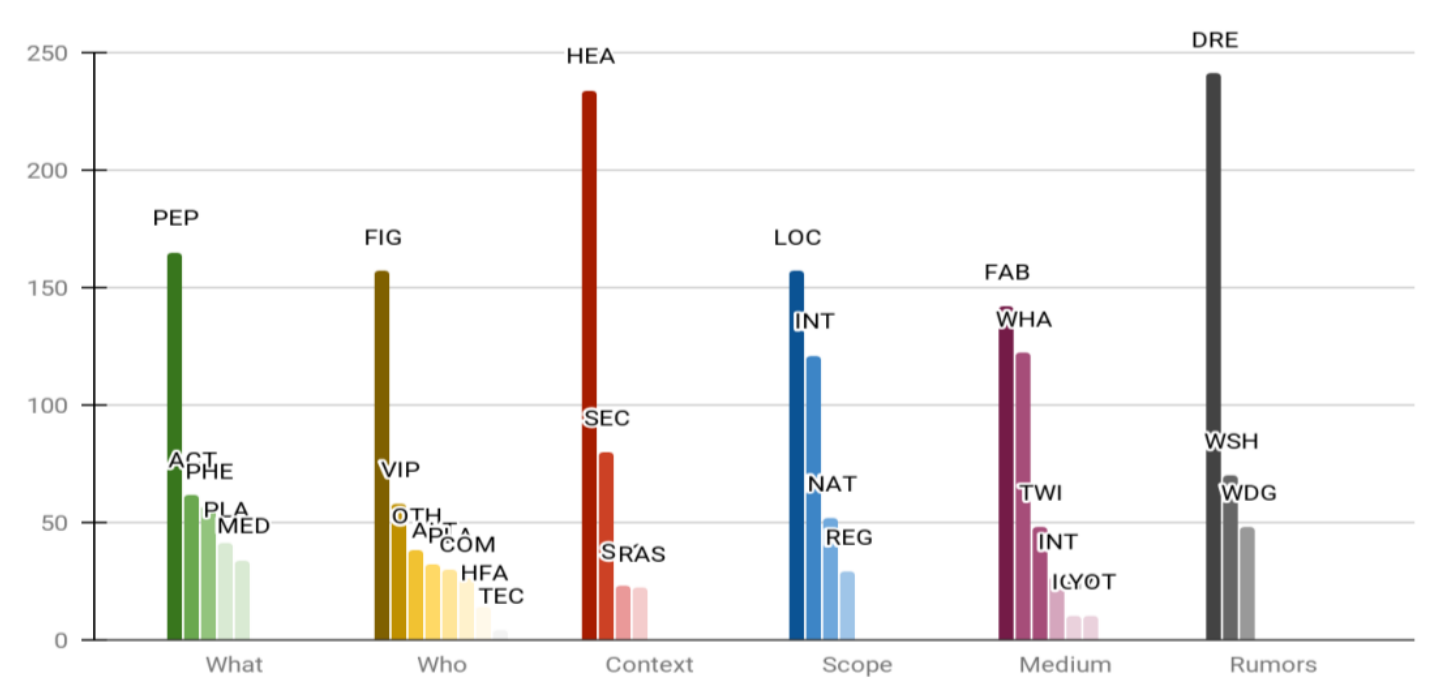

Figure 1. Mapping of Hoaxes

Figure 1 shows 359 Covid-19 pandemic hoaxes in Indonesia from January to the end of March 2020 in each category (see Table 1). This mapping can convey the number of hoaxes for each category and sub-category during the three months of observation. Based on figure 1, the HEA and DRE sub-categories show a high level of hoaxes. HEA relates to a health issue, and DRE is a dread issue. The mapping hoax data during the Covid-19 pandemic in Indonesia because the most common hoaxes from the analysis in January to the end of March 2020 were about health issues targeting fearmongering and implying the general public in local areas with Facebook and WhatsApp as a distribution platform. The second most common hoax of the analysis is alternative medicine and treatment for Covid-19 by implementing global and national security action activities regulated and influenced by key figures from the information distributed through various platforms. The least that can pose a potential danger are hoaxes that incite hatred and sentiment against political preferences, ethnicity, and religious beliefs that threaten harmony at the regional level through various social media platforms. Therefore, a gap is needed in the accessibility of online health information through increasing eHealth literacy to the public(Paek \& Hove, 2012). Paige, Krieger, and Stellefson (2017) research shows that older adults with low eHealth have high trust in Facebook but low trust in online support groups. So, it is not surprising that the level of hoax spread about Covid-19 via Facebook reached $(142,39.6 \%)$, much higher than Twitter.

This study's number of hoaxes cannot describe hoaxes' impact during the ongoing pandemic in Indonesia. However, these numbers can give a glimpse into a situation where rumors or hoaxes are intoxicating the public social media timeline. So, this study's results are in line with Collins et al. (2020) that one of the potentials is to spread disinformation through social media. Rumors that spread fear and uncertainty circulated massively, especially among the surrounding communities. This research also occurred in Indonesia, China, and Russia, namely spreading rumors online (Pulford, 2019). Social media platforms like Facebook and Twitter or group chat apps like WhatsApp contribute to scams' constant danger. The need to educate people with digital and media literacy is imperative(Spires, Paul, \& Kerkhoff, 2018). Lack of skills checks can lead to the way people recognize and distribute. Failure to understand information can also be the cause. Lack of critical thinking in education also tends to contribute to a lack of 
identification of information. This phenomenon worsened during the Covid-19 pandemic, while the government and journalists still struggled to verify and distribute reliable health information(Perreault \& Perreault, 2021). This research also shows that mapping disinformation categories are important for society, especially social media users, to implement the eHealth literacy revolution (Malone, Jo, \& Clifton, 2017)

In addition, hoaxes related to Covid-19 do not only damage the timeline of public social media. They have also crept into people's minds with fear. It is in line with the research results from Viswanath, Lee, and Pinnamaneni (2020) that disinformation amid the Covid-19 pandemic can cause public distrust of the government, media, and even information about each other from various sources distributed on social media facilitated by users. Generated Contents. Meanwhile, the government and media also broadcast their version of Covid-19 information; as Allport and Portman (1946) in Pulford (2019) illustrate, rumors spread in large numbers when data is widely distributed. They show how rumors about the Pearl Harbor attack developed rapidly after the newspaper published the tragedy. However, this study shows that rumors that have occurred in the era of technological advancement have accelerated the spread of disinformation on a large scale (see Table 4). 65.2\% of Covid-19 disinformation related to health occurred, such as "wet tissue can replace your mask". This is due to panic and a lack of health literacy in the community. The information obtained is not analyzed first and is immediately disseminated (Chesser, Burke, Reyes, \& Rohrberg, 2015).

The fears implicit in the Covid-19 disinformation have projected people's emotional state because Allport and Portman (Pulford, 2019) pointed out that when people have less information about their environment, they fail to objectively and impartially understand any information (Saurwein \& Spencer-Smith, 2020). The misleading information on Covid-19 also shows this projection that people who fear their lives will contract the coronavirus will fall easy prey to disinformation(Shirish, Srivastava, \& Chandra, 2021). During a pandemic, an emergency is supposed to alert the public, but disinformation exacerbates the situation. This has had a very significant impact on society. The impact is fear of the local situation, government regulations, and a mistaken belief in medicine and alternative medicine.

Therefore, the study indicates that it is time for the government, academics, and society to improve eHealth literacy $(\mathrm{Li}, 2018)$. eHealth literacy can empower people to understand health-related information better. Also, this study shows that inaccurate and misleading health information often occurs on the Internet, especially through Facebook. Therefore, people need the competence to take advantage of technology in improving eHealth literacy(Chesser et al., 2015). On the other side, the study offers the government, especially the Ministry of Communications and Informatics, has increased socialization to the public, especially through social media related to hoax news reports on the Kominfo website(Shirish et al., 2021). This is to increase public awareness and information literacy against disinformation during the Covid 19 pandemic so that the public can sort out which information is trusted and can be disseminated.

\section{Conclusion}

Based on hoax news reports published through the Ministry of Communications and Informatics website, the highest hoax contexts are health issues. In addition, the disinformation that spread during the Covid 19 pandemic made the public afraid and panicked. The implication of this study suggests several recommendations in response to the urgency of handling disinformation during the Covid-19 in Indonesia, such as 
initiating digital and media literacy in the national education system. The present study can provide a clearer picture to the government and the public about the spread of hoaxes during a pandemic. This research offers the government to work together and carry out fact-checking practices with local stakeholders, especially in rural areas. On the other side, local communities must monitor, check the truth, and clarify misinformation in their community. Each local community from the district, subdistrict, and local community must organize fact-checking the disinformation. Further research is suggested to conduct a more thorough, longitudinal, and comprehensive study of disinformation mapping during Covid-19.

\section{Acknowledgements}

This research results from collaborative research between the University of Indonesia, the State University of Jakarta, and the University of Padjajaran. Therefore, we would like to thank the Chancellors of the University of Indonesia, the State University of Jakarta, and the University of Padjajaran. They have provided material and moral support.

\section{References}

Aaltola, M. (2012). Contagious insecurity: War, SARS and global air mobility. Contemporary Politics, 18(1), 53-70. https://doi.org/10.1080/13569775.2012.651273

Ali, I. (2020). The COVID-19 Pandemic: Making Sense of Rumor and Fear: Op-Ed. Medical Anthropology: Cross Cultural Studies in Health and Illness, 39(5), 376379. https://doi.org/10.1080/01459740.2020.1745481

Arthur, P. L. (2017). Things fall apart: Identity in the digital world. Life Writing, 14(4), 541-550. https://doi.org/10.1080/14484528.2017.1364170

Bahar, H. M. (2020). Social media and disinformation in war propaganda: how Afghan government and the Taliban use Twitter. Media Asia, 47(1-2), 34-46. https://doi.org/10.1080/01296612.2020.1822634

Chesser, A., Burke, A., Reyes, J., \& Rohrberg, T. (2015). Navigating the digital divide: Literacy in underserved populations in the United States. Informatics for Health and Social Care, 41(1), 1-19. https://doi.org/10.3109/17538157.2014.948171

Chou, W. Y. S., Gaysynsky, A., \& Cappella, J. N. (2020). Where we go from here: Health misinformation on social media. American Journal of Public Health, 110(53), S273-S275. https://doi.org/10.2105/AJPH.2020.305905

Collins, B., Hoang, D. T., Nguyen, N. T., \& Hwang, D. (2020). Trends in combating fake news on social media - a survey. Journal of Information and Telecommunication, O(0), 1-20. https://doi.org/10.1080/24751839.2020.1847379

Craufurd Smith, R. (2019). Fake news, French Law and democratic legitimacy: lessons for the United Kingdom? Journal of Media Law, 11(1), 52-81. https://doi.org/10.1080/17577632.2019.1679424

Freelon, D., \& Wells, C. (2020). Disinformation as Political Communication. Political Communication, 37(2), 145-156. https://doi.org/10.1080/10584609.2020.1723755

Guo, L. (2020). China's "Fake News" Problem: Exploring the Spread of Online Rumors in the Government-Controlled News Media. Digital Journalism, 8(8), 992-1010. https://doi.org/10.1080/21670811.2020.1766986

Guo, L., \& Zhang, Y. (2020). Information Flow Within and Across Online Media Platforms: An Agenda-setting Analysis of Rumor Diffusion on News Websites, 
Weibo, and WeChat in China. Journalism Studies, 21(15), 2176-2195. https://doi.org/10.1080/1461670X.2020.1827012

Jamil, S., \& Appiah-Adjei, G. (2020). Battling with infodemic and disinfodemic: the quandary of journalists to report on COVID-19 pandemic in Pakistan. Media Asia, 47(3-4), 88-109. https://doi.org/10.1080/01296612.2020.1853393

Koivisto, A. (2015). Dealing with Ambiguities in Informings: Finnish Aijaa as a "Neutral" News Receipt. Research on Language and Social Interaction, 48(4), 365-387. https://doi.org/10.1080/08351813.2015.1090109

Krafft, P. M., \& Donovan, J. (2020). Disinformation by Design: The Use of Evidence Collages and Platform Filtering in a Media Manipulation Campaign. Political Communication, 37(2), 194-214. https://doi.org/10.1080/10584609.2019.1686094

Lebed, F. (2019). On the Philosophical Definition of Human Play Using the Tools of Qualitative Content Analysis. Sport, Ethics and Philosophy, O(0), 1-19. https://doi.org/10.1080/17511321.2019.1649300

Li, X. (2018). Understanding eHealth Literacy From a Privacy Perspective: eHealth Literacy and Digital Privacy Skills in American Disadvantaged Communities. American Behavioral Scientist, 62(10), 1431-1449. https://doi.org/10.1177/0002764218787019

Malone, T., Jo, P., \& Clifton, S. (2017). Perceived eHealth Literacy and Information Behavior of Older Adults Enrolled in a Health Information Outreach Program. Journal of Consumer Health on the Internet, 21(2), 137-147. https://doi.org/10.1080/15398285.2017.1300040

Mansur, S., Saragih, N., Ritonga, R., \& Damayanti, N. (2021). Fake News on Social Media and Adolescent' s Cognition Berita Palsu di Media Sosial dan Kognisi Remaja. Jurnal ASPIKOM, 6(1), 29-41.

McDougall, J., Brites, M. J., Couto, M. J., \& Lucas, C. (2019). Digital literacy, fake news and education. Cultura Y Educacion, 31(2), 203-212. https://doi.org/10.1080/11356405.2019.1603632

Paek, H. J., \& Hove, T. (2012). Social Cognitive Factors and Perceived Social Influences That Improve Adolescent eHealth Literacy. Health Communication, 27(8), 727-737. https://doi.org/10.1080/10410236.2011.616627

Paige, S. R., Krieger, J. L., \& Stellefson, M. L. (2017). The Influence of eHealth Literacy on Perceived Trust in Online Health Communication Channels and Sources. Journal of Health Communication, 22(1), 53-65. https://doi.org/10.1080/10810730.2016.1250846

Perreault, M. F., \& Perreault, G. P. (2021). Journalists on COVID-19 Journalism: Communication Ecology of Pandemic Reporting. American Behavioral Scientist. https://doi.org/10.1177/0002764221992813

Pulford, E. (2019). Wind from an empty cave? Online rumor and ideology in postsocialist China and Russia. Asian Anthropology, 18(1), 1-20. https://doi.org/10.1080/1683478X.2019.1537060

Rampersad, G., \& Althiyabi, T. (2020). Fake news: Acceptance by demographics and culture on social media. Journal of Information Technology and Politics, 17(1), 1-11. https://doi.org/10.1080/19331681.2019.1686676

Saurwein, F., \& Spencer-Smith, C. (2020). Combating Disinformation on Social Media: Multilevel Governance and Distributed Accountability in Europe. Digital Journalism, 8(6), 820-841. https://doi.org/10.1080/21670811.2020.1765401

Schellekens, T., Dillen, A., Dewitte, L., \& Dezutter, J. (2020). A Lay Definition of 
Grace: A Quantitative and Qualitative Content Analysis. International Journal for the Psychology of Religion, O(0), 1-23. https://doi.org/10.1080/10508619.2020.1793593

Scherr, S., Arendt, F., Prieler, M., \& Ju, Y. (2021). Investigating the negative-cognitivetriad-hypothesis of news choice in Germany and South Korea: does depression predict selective exposure to negative news? The Social Science Journal, 1-18. https://doi.org/10.1080/03623319.2020.1859817

Seo, H. (2014). Visual Propaganda in the Age of Social Media: An Empirical Analysis of Twitter Images During the 2012 Israeli-Hamas Conflict. Visual Communication Quarterly, 21(3), 150-161. https://doi.org/10.1080/15551393.2014.955501

Shirish, A., Srivastava, S. C., \& Chandra, S. (2021). Impact of mobile connectivity and freedom on fake news propensity during the COVID-19 pandemic: a crosscountry empirical examination. European Journal of Information Systems, O(0), 1-20. https://doi.org/10.1080/0960085X.2021.1886614

Spires, H. A., Paul, C. M., \& Kerkhoff, S. N. (2018). Digital Literacy for the 21st Century. In Encyclopedia of Information Science and Technology, Fourth Edition (pp. 2235-2242). https://doi.org/10.4018/978-1-5225-7659-4.ch002

Stanley, M. L., Barr, N., Peters, K., \& Seli, P. (2020). Analytic-thinking predicts hoax beliefs and helping behaviors in response to the COVID-19 pandemic. Thinking and Reasoning, O(0), 1-14. https://doi.org/10.1080/13546783.2020.1813806

Susilo, M. E., Yustitia, S., \& Afifi, S. (2020). Intergeneration Comparison of the Spread Pattern of Hoax: Perbandingan Pola Penyebaran Hoaks Antargenerasi. 5(1), 50-62.

Viswanath, K., Lee, E. W. J., \& Pinnamaneni, R. (2020). We Need the Lens of Equity in COVID-19 Communication. Health Communication, 35(14), 1743-1746. https://doi.org/10.1080/10410236.2020.1837445

Zajc, M. (2015). The Social Media Dispositive and Monetization of User-Generated Content. Information Society, 31(1), 61-67. https://doi.org/10.1080/01972243.2015.977636 